\title{
Effect of Substrate Sterilization and Spawning Method on the Yield and Yield Attributes of Milky White Mushroom (Calocybe indica)
}

\author{
Md. Ferdaus Ahmed ${ }^{1,2, *}$, Md. Jahedur Rahman ${ }^{1}$, Md. Nazrul Islam ${ }^{1}$, Md. Jafar Ullah ${ }^{3}$, \\ Nirod Chandra Sarker ${ }^{4}$ \\ ${ }^{1}$ Department of Horticulture, Sher-e-Bangla Agricultural University, Bangladesh \\ ${ }^{2}$ Department of Agricultural Extension, Khamar Bari, Dhaka, Bangladesh \\ ${ }^{3}$ Department of Agronomy, Sher-e-Bangla Agricultural University, Bangladesh \\ ${ }^{4}$ Mushroom Development Institute, Savar, Dhaka, Bangladesh \\ *Corresponding Author: ferdaus.aht@gmail.com
}

Received December 15,2019; Revised March 9, 2020; Accepted March 19, 2020

Copyright $\odot 2020$ by authors, all rights reserved. Authors agree that this article remains permanently open access under the terms of the Creative Commons Attribution License 4.0 International License

\begin{abstract}
Sterilization of uncomposted substrate is necessary to avoid contamination and promote mycelium growth for getting maximum yield of mushroom. Spawning method is also important for evenly growth of mycelium in the substrate. Therefore, the present experiment was carried out to investigate the impact of substrate sterilization technique and spawning method on yield and yield attributes of $C$. indica. Seven different treatments such as Steam treatment of substrate and spawning in 3 layers $\left(T_{1}\right)$, Steam treatment of substrate and spawning thoroughly $\left(\mathrm{T}_{2}\right)$, Autoclaving of substrate and top spawning $\left(\mathrm{T}_{3}\right)$, Autoclaving of substrate and spawning in 3 layers $\left(\mathrm{T}_{4}\right)$, Autoclaving of substrate and spawning thoroughly $\left(\mathrm{T}_{5}\right)$, Hot water treatment of substrate and spawning in 3 layers $\left(\mathrm{T}_{6}\right)$ and Hot water treatment of substrate and spawning thoroughly $\left(\mathrm{T}_{7}\right)$ were used in this experiment. Mycelium colonization, substrate contamination, days to total harvest, yield and biological efficiency was significantly affected by substrate sterilization technique and spawning method. Faster mycelium colonization, no substrate contamination, highest yield and biological efficiency was recorded in substrate treated with hot water and inoculated in three layers $\left(\mathrm{T}_{6}\right)$. Result revealed that hot water treatment in combination with three layer spawning of rice straw substrate was the best substrate sterilization technique \& spawning method for milky white mushroom cultivation.
\end{abstract}

Keywords Substrate Sterilization, Spawning Method, Calocybe indica

\section{Introduction}

Calocybe indica is a tropical edible mushroom of Indian origin and can be cultivated indoor in high temperature and humidity areas (Purkayastha \& Chandra, 1974). A substrate is an important substance for making spawn and growing mushrooms (Singh et.al. 2017). Milky white mushroom can be cultivated on varieties of cellulosic substrates like, paddy straw, wheat straw, maize stalks, sorghum stalks, pearl millet stalks, sugarcane trace, sugarcane baggase, soya bean straw, cotton waste, coconut coir pith, groundnut haulms etc. (Patel and Trivedi, 2016). But paddy straw is the principal substrate used for its cultivation in Bangladesh. Pani, B. K. (2010) also stated that paddy straw was the best among the substrates as it produced the maximum yield and biological efficiency $(71.2 \% \mathrm{BE})$ of $C$. indica.

Milky white mushroom grew well on uncomposted substrate under artificial indoor condition (Vijaykumar et. al., 2014.). There is no need to compost the substrate for its cultivation as the mycelium can degrade the cellulose, hemicelluloses and lignin by secretion of various extracellular enzymes (Singh et.al. 2017). But for the better mycelial colonization and yield it is necessary to sterilize or pasteurize the substrate. Khan et. al. (2011) stated that substrate sterilization is much more appropriate method for effective and smooth cultivation of mushroom to remove the existence of a number of microorganism. While the composition of substrates for different mushrooms vary greatly and there is variation in the preparation of substrates used for every cultivated species, most substrates are treated with moist heat and then, said to be pasteurized. The process is intended to kill all seeds, 
nematodes, insects and other organisms that flourish at the temperatures used to grow the mushrooms. Substrates are pasteurized by steam to kill off potential competitive microorganisms. When we pasteurize, we kill many organisms, but we expect those that remain to easily controlled, poor competitors and beneficial to the organism we intend to grow. Substrate pre-treatment namely; steaming for 30 minutes or soaking in hot water $\left(80^{\circ} \mathrm{C}\right)$ for 60 minutes are recommended for commercial purpose (Bokaria, et. al. 2014). Pani, B.K (2010) stated that 6 hours of soaking the substrate and steaming for 60 minutes yielded the maximum production with $0.6 \%$ contamination which was found to be economically viable. Pathan (2009) also stated that the maximum percent yield was in case of soaking and boiling of substrate for 75 minutes (61.75\%). The pasteurized substrate is allowed to cool for the next 16 - 20 hours (Kurtzman, 2010).

In mushroom growing technology the inoculum is known as the "spawn". Spawn is a medium that is impregnated with mycelium made from a pure culture of the chosen mushroom strain. The purpose of the spawn is to boost the mycelium to a state of vigor such that it will rapidly colonies the selected bulk growing substrate. Substrate can be spawning by different ways such as thorough mixing, layer spawning, top spawning etc. Spawning method may have influence on evenly mycelium running in the bulk substrate. But no research work has been conducted on the effect of substrate sterilization and spawning method on milky white mushroom cultivation in Bangladesh.

Therefore, the present study was conducted to find out appropriate substrate sterilization technique and spawning method for better mycelium run in the substrate and achieve a good yield.

\section{Materials and Methods}

The experiment was conducted at Mushroom Development Institute (MDI), Department of Agricultural Extension, Savar, Dhaka, Bangladesh from May to July 2018.

\section{Treatments}

Seven different treatments of substrate sterilization technique in combination with spawning methods namely $\mathrm{T}_{1}=$ Steam treatment of substrate and spawning in 3 layers, $\mathrm{T}_{2}=$ Steam treatment of substrate and spawning thoroughly, $\mathrm{T}_{3}=$ Autoclaving of substrate and top spawning, $\mathrm{T}_{4}=$ Autoclaving of substrate and spawning in 3 layers, $\mathrm{T}_{5}=$ Autoclaving of substrate and spawning thoroughly, $\mathrm{T}_{6}=$ Hot water treatment of substrate and spawning in 3 layers and $\mathrm{T}_{7}=$ Hot water treatment of substrate and spawning thoroughly were used in this experiment.

\section{Steam Treatment}

Rice straw was used for the cultivation of milky white mushroom. The straw was chopped to convenient length of 2.5 to $5 \mathrm{~cm}$. The substrate was mixed with appropriate amount of water and then filled in net bag. The net bag filled with substrate were placed in the sterilization cum inoculation chamber. Door of the chamber was closed and tightened with the help of screws. Water heater was turned on to produce steam that flows in to the chamber. When the temperature of the chamber rises to $60^{\circ} \mathrm{C}$, the steam flow was adjusted to maintain a constant temperature of $70^{\circ} \mathrm{C}-$ $80^{\circ} \mathrm{C}$ up to 90 minutes. After 90 minutes water heater was turned off and kept it for about 20 hours. After 20 hours substrate was taken out and used for preparation of spawn packet.

\section{Autoclaving}

In case of treatment $T_{3}$ substrate was mixed with appropriate amount of water and then filled into the polythene bags (12"x16") and autoclaved in an autoclave machine for 2 hours at $121^{\circ} \mathrm{C}$ and $1.5 \mathrm{~kg} / \mathrm{cm}^{2}$ pressure. For treatment $\mathrm{T}_{4}$ and $\mathrm{T}_{5}$ water mixed substrate was filled into net bag and autoclaved in the same way. Upon cooling substrate was used for spawn packet preparation.

\section{Hot Water Treatment}

Rice straw substrate chopped to convenient length of 2.5 to $5 \mathrm{~cm}$ was poured into a net bag and treated with hot water at $60^{\circ} \mathrm{C}$ in a drum for 60 minutes and allowed to drain out the excess water by hanging the bag for 20 hours. The moisture content of the hot water treated substrate was allowed to leave by spreading them on plastic sheet so that excess moisture was evaporated to obtain 55 to 60 percent moisture.

\section{Spawning}

For treatment $T_{1}, T_{4}$ and $T_{6}$ pasteurized/sterilized substrate was filled into the polythene bags (12"x16") and inoculated with $10 \%$ sawdust mother culture in three layers. For treatment $\mathrm{T}_{3}$ autoclave sterilized substrate bags were inoculated with sawdust mother culture on the top of the substrate through the neck. For treatment $T_{2}, T_{5}$ and $T_{7}$ pasteurized/sterilized substrate was filled into the polythene bags (12"x16") and inoculated with $10 \%$ sawdust mother culture by thorough mixing. Then the spawn packets were transferred to the culture house for mycelium run. After 16-25 days the substrate was completely colonized by the mycelium and polythene cover was opened.

\section{Casing and after Care}

Loamy soil was used as casing material and was sterilized at $65^{\circ} \mathrm{C}$ for 4 hours. Casing material was covered over the mycelium on the substrate up to $4 \mathrm{~cm}$ thickness. 
Watering was done at regular interval to maintain moisture at 60 to $70 \%$. Primordia initiated at 8-14 days and developed in to fruiting bodies.

The fruiting bodies were harvested at 7-8 days of primordia initiation and data were collected on days to complete spawn run, rate of spawn packet contamination, days to primordia initiation, length of stalk, diameter of stalk, diameter of pileus, thickness of pileus, number of effective fruiting body (NEFB), days to final harvest, yield and biological efficiency (BE). The BE was measured by the formula;

$\mathrm{BE}=($ Fresh weight of mushroom/ Dry weight of substrate $)$ $\mathrm{x} 100$

\section{Data Analysis}

The experiment was laid out in Completely Randomized Design (CRD) with 4 replications. The data were statistically analyzed following SPSS (version 20.0) computer program. Difference among the treatment means were determined by Tukey's Test (Tukey, 1977) at $P \leq$ 0.05 .

\section{Result and Discussion}

\section{Days to Complete Mycelium Run in the Spawn Packet and Rate of Substrate Contamination}

Mycelium run in the spawn packet are shown in Table-1 and percent substrate contamination in Figure-1. Mycelium colonization was faster (16.50 days) in substrate treated with hot water and inoculated by thorough spawning $\left(\mathrm{T}_{7}\right)$ which was statistically similar (18.25 days) to substrate treated with hot water and inoculated in three layers $\left(\mathrm{T}_{6}\right)$. Slowest colonization was observed in steam treated substrate inoculated by 3 layer spawning $\left(\mathrm{T}_{1}\right)$ and thorough spawning $\left(T_{2}\right)$ (24.25 days). Mycelium run was almost zero and substrate contamination was very high $(90 \%)$ in substrate sterilized by autoclaving and spawning through the neck $\left(\mathrm{T}_{3}\right)$ which was significantly different from other treatments. The rate of substrate contamination was zero in substrate treated with hot water and inoculated by thorough spawning $\left(\mathrm{T}_{7}\right)$ and substrate treated with hot water and inoculated by 3 layer spawning $\left(T_{6}\right)$ which was statistically similar to $\mathrm{T}_{4}(25 \%)$ and $\mathrm{T}_{1}(35 \%)$. Result suggested that hot water treatment of rice straw substrate was the best substrate sterilization technique of milky white mushroom. Sarker et.al. (2012) also reported similar result in case of $V$. volvacea. Highest rate of contamination of spawn packet in $\mathrm{T}_{3}$ might be due to lack of proper aeration and less amount of mother culture used.

In column figures having same letters do not differ significantly at $5 \%$ level according to Tukey's test. T1= Steam treatment of substrate and spawning in 3 layers, $\mathrm{T} 2=$ Steam treatment of substrate and spawning thoroughly, $\mathrm{T} 3=$ Autoclaving of substrate and top spawning, $\mathrm{T} 4=$
Autoclaving of substrate and spawning in 3 layers, T5= Autoclaving of substrate and spawning thoroughly, T6= Hot water treatment of substrate and spawning in 3 layers and $\mathrm{T} 7=$ Hot water treatment of substrate and spawning thoroughly.

Table 1. Effect of substrate sterilization technique and spawning methods on spawn run, primordia initiation and harvesting time of milky white mushroom (Calocybe indica)

\begin{tabular}{|c|c|c|c|}
\hline Treatments & $\begin{array}{c}\text { Days to } \\
\text { Spawn run }\end{array}$ & $\begin{array}{c}\text { Days to primordia } \\
\text { initiation }\end{array}$ & $\begin{array}{c}\text { Days to last } \\
\text { harvest }\end{array}$ \\
\hline $\mathrm{T}_{1}$ & $24.25 \mathrm{a}$ & $8.63 \mathrm{~b}$ & $33.25 \mathrm{c}$ \\
\hline $\mathrm{T}_{2}$ & $24.25 \mathrm{a}$ & $14.28 \mathrm{a}$ & $35.50 \mathrm{bc}$ \\
\hline $\mathrm{T}_{3}$ & 00.00 & 00.00 & 00.00 \\
\hline $\mathrm{T}_{4}$ & $20.50 \mathrm{c}$ & $10.13 \mathrm{~b}$ & $33.00 \mathrm{c}$ \\
\hline $\mathrm{T}_{5}$ & $22.25 \mathrm{~b}$ & $13.00 \mathrm{a}$ & $39.00 \mathrm{~b}$ \\
\hline $\mathrm{T}_{6}$ & $18.25 \mathrm{~cd}$ & $9.15 \mathrm{~b}$ & $51.00 \mathrm{a}$ \\
\hline $\mathrm{T}_{7}$ & $16.50 \mathrm{~d}$ & $8.85 \mathrm{~b}$ & $35.75 \mathrm{bc}$ \\
\hline $\mathrm{P}$ & $<0.001$ & $<0.001$ & $<0.001$ \\
\hline
\end{tabular}

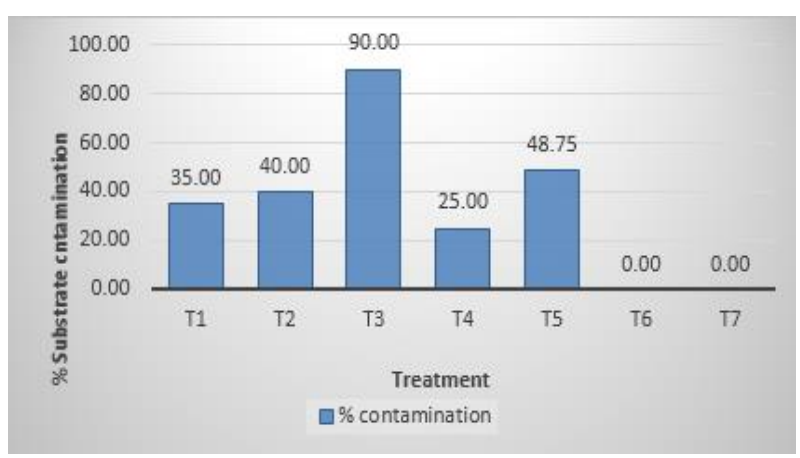

Figure 1. Effect of substrate sterilization and spawning method on substrate contamination

\section{Days to Primordia Initiation and Last Harvest}

Days required for fruiting body primordia initiation after casing was minimum (8.63 days) in steam treated substrate inoculated by 3 layer spawning $\left(\mathrm{T}_{1}\right)$ which was statistically similar to $\mathrm{T}_{7}, \mathrm{~T}_{6}$ and $\mathrm{T}_{4}$ (Table-1). Maximum time was required (14.28 days) in steam treated substrate inoculated by thorough spawning $\left(\mathrm{T}_{2}\right)$ which was similar to $\mathrm{T}_{5}(13.0$ days). As the maximum spawn packet was contaminated, it was not possible to analyze data from $\mathrm{T}_{3}$. Patra and Pani (1995) reported that time required for primordia initiation of $C$. indica was 13-16 days. Sarker et.al. (2012) reported that days required for primordia initiation of $V$. volvacea in all substrate sterilization treatments was statistically similar. This might be difference of substrate sterilization technique. Highest time (51.0 days) was required for complete the crop harvest from casing in hot water treated substrate inoculated in 3 layer spawning $\left(\mathrm{T}_{6}\right)$ which was significantly different from other treatments. Lowest time 
(33.0 days) was required in autoclaved substrate inoculated by 3 layer spawning $\left(T_{4}\right)$ which was similar to $T_{1}, T_{2}$ and $T_{7}$. Highest time required for crop harvest might be due to more fruiting body production and yield in $\mathrm{T}_{6}$.

\section{Number and Size of Fruiting Body}

Highest number of effective fruiting body (NEFB) per packet (6.83) was observed in hot water treated substrate inoculated in 3 layer spawning $\left(\mathrm{T}_{6}\right)$ which was similar to $\mathrm{T}_{7}$ (6.70) and $\mathrm{T}_{4}$ (6.33). Lowest NEFB was observed in steam treated substrate inoculated by thorough spawning $\mathrm{T}_{2}$ (3.90). Sarker et.al. (2012) also reported that highest number of effective fruiting body of $V$. volvacea was recorded with hot water sterilization of rice straw substrate.

Length of stalk was slightly influenced by substrate sterilization and spawning method but there was no significant effect was observed on stalk diameter (Table-2). Highest stalk length $(8.83 \mathrm{~cm})$ was observed in autoclaving of substrate and inoculated by 3 layer spawning $\left(\mathrm{T}_{4}\right)$ which was statistically similar to all other treatments except $\mathrm{T}_{7}$ $(6.58 \mathrm{~cm})$. Highest stalk diameter was observed in $\mathrm{T}_{1}(2.85$ $\mathrm{cm})$ and lowest in $\mathrm{T}_{4}(2.45 \mathrm{~cm})$ but there was no significant difference among the treatments. Pileus dimeter was maximum in $\mathrm{T}_{1}(6.95 \mathrm{~cm})$ and minimum in $\mathrm{T}_{2}(5.65 \mathrm{~cm}) . \mathrm{T}_{2}$ was significantly different from $\mathrm{T}_{1}$ but was similar to other treatments. Highest thickness of pileus $(2.80 \mathrm{~cm})$ was observed in $T_{1}$ which was significantly different from $T_{6}$ but was similar to all other treatments.

In column figures having same letters do not differ significantly at $5 \%$ level according to Tukey's test. T1= Steam treatment of substrate and spawning in 3 layers, $\mathrm{T} 2=$ Steam treatment of substrate and spawning thoroughly, $\mathrm{T} 3=$ Autoclaving of substrate and top spawning, T4= Autoclaving of substrate and spawning in 3 layers, T5= Autoclaving of substrate and spawning thoroughly, T6= Hot water treatment of substrate and spawning in 3 layers and $\mathrm{T} 7=$ Hot water treatment of substrate and spawning thoroughly.

Table 2. Effect of substrate sterilization technique and spawning methods on fruiting body of milky white mushroom (Calocybe indica)

\begin{tabular}{|c|c|c|c|c|c|}
\hline Treatments & $\begin{array}{c}\text { No. of effective fruiting } \\
\text { body }\end{array}$ & $\begin{array}{c}\text { Length of Stalk } \\
(\mathrm{cm})\end{array}$ & $\begin{array}{c}\text { Diameter of Stalk } \\
(\mathrm{cm})\end{array}$ & $\begin{array}{c}\text { Diameter of Pileus } \\
(\mathrm{cm})\end{array}$ & $\begin{array}{c}\text { Thickness of Pileus } \\
(\mathrm{cm})\end{array}$ \\
\hline T1 & $4.30 \mathrm{c}$ & $8.33 \mathrm{a}$ & $2.85 \mathrm{a}$ & $6.95 \mathrm{a}$ & $2.80 \mathrm{a}$ \\
\hline $\mathrm{T} 2$ & $3.90 \mathrm{c}$ & $8.33 \mathrm{a}$ & $2.65 \mathrm{a}$ & $5.65 \mathrm{~b}$ & 00.00 \\
\hline T3 & 00.00 & 00.00 & 00.00 & 00.00 & $2.63 \mathrm{ab}$ \\
\hline T4 & $6.33 \mathrm{ab}$ & $8.83 \mathrm{a}$ & $2.45 \mathrm{a}$ & $5.75 \mathrm{~b}$ & $2.50 \mathrm{ab}$ \\
\hline T5 & $4.96 \mathrm{bc}$ & $8.18 \mathrm{a}$ & $2.50 \mathrm{a}$ & $5.78 \mathrm{ab}$ & $2.28 \mathrm{~b}$ \\
\hline T6 & $6.83 \mathrm{a}$ & $7.58 \mathrm{ab}$ & $2.48 \mathrm{a}$ & $6.20 \mathrm{ab}$ & $2.45 \mathrm{ab}$ \\
\hline T7 & $6.70 \mathrm{a}$ & $6.58 \mathrm{~b}$ & $2.65 \mathrm{a}$ & $=0.025$ & $=0.046$ \\
\hline P & $<0.001$ & $=0.002$ & $=0.230$ & & \\
\hline
\end{tabular}




\section{Yield and Biological Efficiency}

Yield and Biological efficiency was significantly influenced by spawning method and substrate sterilization technique (Figure-2). Maximum yield (296.31 g/packet) and biological efficiency $(73.16 \%)$ was recorded in hot water treated substrate spawning in 3 layers $\left(\mathrm{T}_{6}\right)$ which was similar to $\mathrm{T}_{7}(69.3 \%)$ and $\mathrm{T}_{4}(66.96 \%)$. Lowest yield (165.06 g/packet) and biological efficiency (38.54\%) was in steam treated substrate inoculated by thorough spawning $\left(\mathrm{T}_{2}\right)$ which was significantly lower than all other treatments. No yield was recorded from $\mathrm{T}_{3}$ because of $90 \%$ spawn packet was contaminated. Result revealed that hot water treated substrate spawning in 3 layers of rice straw substrate was the best substrate sterilization technique and spawning method of milky white mushroom cultivation. Sarker et.al. (2012) also reported similar result in case of $V$. volvacea. Suman et.al. (2018) reported that biological efficiency of $C$. indica was $61.9 \%$ in rice straw substrate.

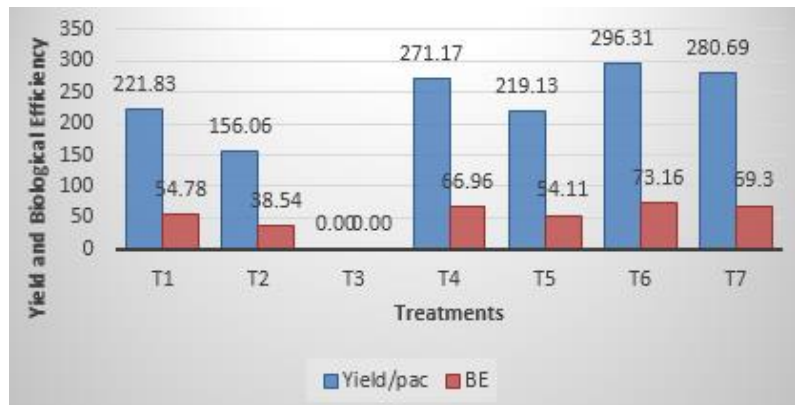

Figure 2. Effect of substrate sterilization and spawning method on yield and biological efficiency of milky white mushroom (Calocybe indica)

\section{Conclusions}

In conclusion, the values obtained for mycelium growth, substrate contamination, yield contributing parameters and biological efficiency of milky white mushroom for treatment $\mathrm{T}_{6}$ were better than those obtained from other treatments. Thus substrate treated with hot water and inoculated by three layer spawning $\left(\mathrm{T}_{6}\right)$ can be used for milky white mushroom cultivation as it provides no contamination and highest biological efficiency.

\section{REFERENCES}

[1] Bokaria, K., Balsundram, S. K., Bhattarai, I. and Kaphle, K. 2014. Merit Research Journal of Agricultural Science and Soil Sciences 2(2):032-037.

[2] Chakravarty, D. K., Sarkar, B. B. and Kundu, B. M. 1981. Cultivation of tropical edible mushroom Calocybe indica. Current Science. 50:550-555.

[3] Vijaykumar, G., John, P., and Gonesh, K. 2014. Selection of different substrate for the cultivation of milky mushroom (Calocybe indica $P \& C$ ). Indian Journal of traditional knowledge. 13(2):334-336.

[4] Khan, N. A., Abbas, M., Rehman, A., Haq, I. and Hannan, A. 2011. Impact of various sterilization methods using different substrates for yield improvement of Pleurotys spp. Pak. J. Phytopathol. 23(1): 20-23.

[5] Krishnamoorthy, A. S., Muthuswamy, M. T., Nakkeeran, S. 2000. Technique for commercial production of milky mushroom Calocybe indica $\mathrm{P} \& \mathrm{C}$. Indian J Mushrooms.18:19-23.

[6] Kurtzman, R. H. 2010. Pasteurization of mushroom substrate and other solids. African Journal of Environmental Science and Technology. 4(13):936-941.

[7] Pani, B.K. 2010. Evaluation of some substrates for cultivation of white summer mushroom (calocybe indica). Res. J. Agric. Sci. 1(4): 357359.

[8] Patel, P. and Trivedi, R. 2016. Yield Performance of Calocybe indica on Different Agricultural Subatrate. International Research Journal of Engineering, IT and Scientific Research. 2(3):105-111.

[9] Patra, A. K.\& Pani, B. K. 1995. Yield response of different species of oyster mushroom (Pleurotus) to paddy straw. Curr. Agric. Res. 8:11-14.

[10] Purkayastha, R. P. and Chandra, A. 1974. New species of edible mushroom from India. Trans. Br. Mycol. Soc. 62: 415418 .

[11] Singh, V., Kumar, P., Kumar, S. and Kumar, K. 2017. Yield Performance of Collected Wild Milky Mushroom (Calocybe SP.) Vol. 17 No. 1, pp. 181-186.

[12] Suman, S. K., Kumar, M. and Dayaram. 2018. Evaluation of Substrate on Production of Calocybe indica (Milky white mushroom) under Bihar Condition. Int. J. Curr. Microbiol. App. Sci. Special Issue-7: 3694-3699.

[13] Sarker, N. C., Singha, S. M., Moonmoon, M., Rahman, T. and Alam, N. 2012. Performance of Different Sterilization Techniques of Rice Straw Substrate on Yield of Volvariella volvacea. 6(1):31-36.

[14] Tukey, J. W. 1977. Exploratory data analysis. Addision-Wesley, Reading, PA. 